\title{
Bactericidal Effect of the Leaf Extract from Musa spp. (AAB Group, Silk Subgroup), cv. "Manzano" Against Multidrug-Resistant Mycobacterium tuberculosis
}

\author{
Gloria María Molina-Salinas, Andrés Humberto Uc-Cachón,, Luis Manuel Peña-Rodríguez, ${ }^{1}$ \\ Angel de Jesús Dzul-Beh, ${ }^{1}$ and Rosa María Escobedo Gracía-Medrano ${ }^{3}$ \\ ${ }^{1}$ Unit of Medical Research Yucatan, Medical Unit of High Specialty, Specialty Hospital 1, \\ Mérida, Yucatan, Mexican Social Security Institute, IMSS, Mexico. \\ ${ }^{2}$ Plant Biotechnology Unit, Yucatan Center for Scientific Research, Mérida, Mexico. \\ ${ }^{3}$ Plant Molecular Biology and Biochemistry Unit, Yucatan Center for Scientific Research, Mérida, Mexico.
}

\begin{abstract}
Air-dried leaves of a Musa spp. AAB, cv. "Manzano" plant, known as Ja'as in the Maya culture, were sequentially extracted with hexane, ethyl acetate, and methanol; the resulting extracts were investigated for their antimycobacterial activity against susceptible and drug-resistant strains of Mycobacterium tuberculosis (MTB) using the Microplate Alamar Blue Assay. Both the n-hexane extract (HE) and ethyl acetate extract (EE) showed potent activity against both strains of MTB, with the EE exhibiting the strongest activity and a Minimum Inhibitory Concentration of 12.5 and $6.25 \mu \mathrm{g} / \mathrm{mL}$ against susceptible and drug-resistant strains, respectively. Both extracts also demonstrated a mycobactericidal effect and a very good selectivity index when tested for cytotoxic activity on Vero monkey kidney cells, using the Sulforhodamine B assay. Our results demonstrate the efficiency and selectivity of Musa spp. AAB, cv. "Manzano" against MTB strains and support its traditional use as remedy against tuberculosis in Maya traditional medicine.
\end{abstract}

KEYWORDS: • antimycobacterial • banana $\bullet$ tuberculosis

\section{INTRODUCTION}

$\mathbf{T}$ UBERCUlosis (TB) IS AN INFECTIOUS DISEASE caused mainly by Mycobacterium tuberculosis (MTB). TB is among the first 10 causes of death worldwide, and it is estimated that 1.7 billion persons have a latent TB infection. There are $\sim 10$ million new TB cases of TB worldwide and an estimated 1.6 million individuals died as a result of TB in 2017. ${ }^{1}$ Inappropriate anti-TB treatments have led to the emergence of multidrug-resistant (MDR, resistant to at least first-line drugs isoniazid and rifampin), extensively drugresistant (XDR, resistant to at least isoniazid, rifampin, one fluoroquinolone, and one of three injectable second-line drugs), and totally drug-resistant (TDR, resistant to all firstand second-line drugs) strains of MTB. ${ }^{1-3}$ Therefore, the

\footnotetext{
Manuscript received 2 April 2019. Revision accepted 19 May 2019.
}

Address correspondence to: Gloria María Molina-Salinas, PhD, Unidad de Investigación Médica Yucatán, Unidad Médica de Alta Especialidad Hospital de Especialidades 1 Mérida, Yucatán, Instituto Mexicano del Seguro Social, Calle 34 No. 439 X 41, Colonia Industrial,97150 Mérida, Yucatán, México, E-mail: gmolina70@gmail.com

(C) Gloria María Molina-Salinas et al. 2019; Published by Mary Ann Liebert, Inc. This Open Access article is distributed under the terms of the Creative Commons Attribution Noncommercial License (http://creativecommons.org/licenses/by-nc/4.0/) which permits any noncommercial use, distribution, and reproduction in any medium, provided the original author(s) and the source are cited. emergence of these strains urgently requires the development of novel, fast-acting, and highly effective anti-TB drugs.

Plants and plant products have long been used as treatment for disease conditions with symptoms of TB in different traditional medicines around the world. Medicinal plants have become subject to scientific investigations worldwide and their active components provide a potential alternative for the development of new drug candidates in the treatment of TB. ${ }^{4-6}$ Various components of the banana (genus Musa) plant have been used in traditional medicine for the treatment of health problems such as diarrhea, dysentery, intestinal lesions, diabetes, uremia, nephritis, gout, hypertension, cardiac disease, and TB..$^{7,8}$

We have recently reported that the leaf and rhizome extracts of Musa $\times$ paradisiaca var. Tabasco possesses activity against an MDR-MTB strain. ${ }^{9}$ On continuing with our search for anti-TB activity in banana, we wish to report the anti-TB activity of the leaf extracts of Musa spp. AAB, cv. "Manzano" when tested against susceptible and drugresistant strains of MTB. The plant Musa spp. AAB, cv. "Manzano," commonly known as Ja'as in the Maya culture, whose leaves are used to wrap "tamales" for cooking and serving, has also been documented for the use of its leaf $\mathrm{sap}^{10}$ and pseudostem sap ${ }^{11,12}$ for the treatment of TB. The remedy is prepared with the plant's pseudostems and leaves, which are ground, squeezed, sweetened, and sneaked; its 
extract is refreshed overnight by the dew for human consumption on an empty stomach. ${ }^{13}$

The leaves of Musa spp. AAB, cv. "Manzano" were obtained in June 2017 from the Musaceae live collection maintained by "Centro de Investigación Científica de Yucatán" in the experimental fields of "Instituto Nacional de Investigaciones Forestales, Agrícolas y Pecuarias" in Uxmal, Yucatán, Mexico (20 24 $27.72^{\circ}$ ' Lat. N, and $89^{\circ} 45^{\prime}$ 06.66"' Long. W, elevation $44.0 \mathrm{~m}$ above sea level).

The air-dried powdered leaves of Musa spp. ABB, cv. "Manzano" (15g) were sequentially extracted with nhexane, ethyl acetate, and methanol $(3 \times 150 \mathrm{~mL})$, at room temperature by soaking the plant material for $24 \mathrm{~h}$ in an orbital shaker at $0.106 \mathrm{~g}$. Each extract was filtered and evaporated the solvent in vacuo.

In vitro anti-TB activity was determined using the modified Microplate Alamar Blue Assay, carried out as previously described.${ }^{14}$ Each of the extracts was dissolved with dimethyl sulfoxide (DMSO) and all the samples were tested using a concentration range of $200-1.56 \mu \mathrm{g} / \mathrm{mL}$. The final concentration of DMSO in all assays was $2.5 \%$ or less, which is nontoxic for mycobacteria. ${ }^{14}$ The results are reported as the minimum inhibitory concentration (MIC). Rifampin or ofloxacin was included as positive controls. In addition, the uninoculated culture medium and DMSO were included as negative and solvent controls, respectively. All evaluations were carried out in three independent assays. Evaluation was performed utilizing two strains of MTB, that is, H37Rv ATTC 27294, susceptible (S-MTB) to all five (streptomycin, isoniazid, rifampin, ethambutol, and pyrazinamide) first-line anti-TB drugs, and the clinical isolate CIBIN 99 (MDR-MTB), known to be resistant to first-line drugs. Each of the previously mentioned strains was cultured in supplemented Middlebrook 7H9, and turbidity was adjusted to a McFarland No. 1 standard. This suspension was further diluted 1:50 with the same culture medium to obtain the test inoculum $\left(\sim 6 \times 10^{6}\right.$ colony-forming units $\left./ \mathrm{mL}\right)$. In addition, the most active extracts (MIC of $\leq 25 \mu \mathrm{g} / \mathrm{mL}$ ) were assayed for mycobactericidal activity using the method previously described in the literature. ${ }^{14}$

In vitro cytotoxic activity on the Vero cell line (ATCC CCL-8) was determined by the Sulforhodamine B method. ${ }^{15}$ Extracts were dissolved with DMSO and tested at a concentration range of $400-25 \mu \mathrm{g} / \mathrm{mL}$. The concentration of DMSO (maximal 1\%) did not affect the viability of the cells. ${ }^{16}$ The results were expressed as the concentration of extract that was lethal for $50 \%$ of the cells (median Cytotoxic Concentration $\left[\mathrm{CC}_{50}\right]$ ). Docetaxel and the culture medium together with DMSO were utilized as positive and solvent controls, respectively. All evaluations were performed in three independent assays, and values were calculated using GraphPad Prism ver. 5 software.

The testing of all extracts for anti-TB activity demonstrated significant activity (MIC values of $6.25-50 \mu \mathrm{g} / \mathrm{mL}$ ) (Table 1), in that crude extracts are considered to possess high potential when exhibiting MIC values below $100 \mu \mathrm{g} / \mathrm{mL}$, moderate when values are $100<\mathrm{MIC}<625 \mu \mathrm{g} / \mathrm{mL}$, and low when the values are MIC $>625 \mu \mathrm{g} / \mathrm{mL} .{ }^{17}$ Among the extracts,
Table 1. Biological Activities of Leaf Extracts From Musa SPP. AAB, CV. "MAnZano"

Anti-TB activity $M I C \mu g / m L$

\begin{tabular}{lccc}
\cline { 2 - 3 } Leaf extracts & $S-M T B(S I)$ & MDR-MTB (SI) & Vero cells $C_{50} \mu \mathrm{g} / \mathrm{mL}$ \\
\hline $\mathrm{HE}$ & $25(15.5)$ & $12.5(31.1)$ & 388.50 \\
$\mathrm{EE}$ & $12.5(7.2)$ & $6.25(14.4)$ & 89.98 \\
ME & 50 & 25 & $>400$ \\
Rifampin & 0.06 & 100 & - \\
Ofloxacin & 0.25 & 0.50 & - \\
Docetaxel & - & - & 1.68
\end{tabular}

Anti-TB: antituberculosis activity; $\mathrm{CC}_{50}$, median cytotoxic concentration; EE, ethyl acetate extract; HE, n-hexane extract; MDR-MTB, Mycobacterium tuberculosis CIBIN 99 (resistant); ME, methanol extract; MIC, minimum inhibitory concentration; S-MTB, M. tuberculosis H37Rv (susceptible); SI, Selectivity Index defined as $\mathrm{CC}_{50}$ Vero cells/MIC MTBs.

the strongest activity was shown by the ethyl acetate extract (EE), with MIC values of 12.5 and $6.25 \mu \mathrm{g} / \mathrm{mL}$ against the S-MTB and MDR-MTB strains, with the drug-resistant strain twice as susceptible to the EE than the susceptible strain. Testing of the most active extracts for mycobactericidal activity showed that the minimum bactericidal concentration values were identical to the MIC values. This is particularly relevant, because anti-TB agents with bactericidal activity are desirable to prevent relapse and reduce to the risk of developing resistance in MTB. ${ }^{18}$

Although plants used medicinally are widely assumed to be safe, many are potentially toxic. Toxicity studies help to ensure that the observed biological activity of the plant extract is not due to a general metabolic toxic effect. A good selectivity index (SI) is an indication of a large safety margin between the concentration of the extract that is able to kill the mycobacteria and the concentration that is toxic to mammalian Vero cells; in this case, a remedy or a candidate compound to be used medicinally must have an SI of $\geq 10^{5,19}$ In this investigation, the two extracts with the strongest mycobactericidal activities revealed very good SI values (Table 1), even though the EE appeared to be more cytotoxic $\left(\mathrm{CC}_{50}\right.$ of $\left.89.98 \mu \mathrm{g} / \mathrm{mL}\right)$ than the hexane extract $\left(\mathrm{CC}_{50}\right.$ of $\left.388.50 \mu \mathrm{g} / \mathrm{mL}\right)$. It is noteworthy that the HE (nhexane extract), with moderate mycobactericidal activity, exhibited the highest SI values in susceptible $(\mathrm{SI}=15.54)$ and MDR (SI = 31.08) MTB strains.

The anti-TB activity of the $\mathrm{HE}$ ( $\mathrm{MIC}=12.5 \mu \mathrm{g} / \mathrm{mL}$ ) and $\mathrm{EE}(\mathrm{MIC}=6.25 \mu \mathrm{g} / \mathrm{mL})$ from leaves of Musa spp. AAB, cv "Manzano" is 50 and 100 times more potent than that recently reported for the hexane extract of the air-dried leaves of Musa paradisiaca var. Tabasco vs. the MDR-MTB strain. ${ }^{9}$ Even though leaf extracts from $M$. paradisiaca, $M$. acuminata, and $M$. sapientum have been reported to show antibacterial (Escherichia coli, Pseudomonas aeruginosa, Proteus mirabilis, Citrobacter spp., Enterobacter aerogenes, Klebsiella pneumonia, Shigella flexneri, Enterococcus faecalis, and Staphylococcus aureus), and leishmanicidal activities. ${ }^{20,21}$ To date, knowledge about the biological activity and phytochemical composition of Musa spp. AAB, cv. "Manzano" is limited or nonexistent. 
With the emergence of drug-resistant strains of MTB, length of the therapy, the high levels of drug toxicity, and their various adverse effects, there is an urgent need to search for novel and more effective anti-TB agents. The use of medicinal plants, or natural plant products, for the treatment of TB represents an important option due to their use in the practice of traditional medicine and their large chemical diversity, respectively. ${ }^{22}$ Our results demonstrate the efficacy and selectivity of using the HE and EE of airdried leaves of Musa spp. AAB, cv. "Manzano" against susceptible and drug-resistant strains of MTB.

In addition, our results support the traditional use of $\mathrm{Musa}$ spp. AAB, cv. "Manzano" to treat TB referred in Maya medicine.

\section{ACKNOWLEDGMENTS}

This research was supported by Fondo de Investigación en Salud, Instituto Mexicano del Seguro Social, FIS/IMSS/PROT/G13/1218 (R-2012-785-041). The authors are grateful to Maggie Brunner, MA, for the English language review of this article and to José $\mathrm{R}$. Ku-Cauich for technical help on collecting the plant material.

\section{AUTHOR DISCLOSURE STATEMENT}

No competing financial interests exist.

\section{REFERENCES}

1. Global tuberculosis report. World Health Organization, Geneva, 2018. https://apps.who.int/iris/bitstream/handle/10665/274453/ 9789241565646-eng.pdf?ua=1 (accessed March 2019).

2. Velayati AA, Farnia P, Masjedi MR: Letter to editor. The totally drug resistant tuberculosis (TDR-TB). Int J Clin Exp Med 2013; 6:307-309.

3. del Olmo-Fernández E, López-Pérez JL, San Feliciano A, García AE: Development of new antituberculosis agents. Enf Emerg 2005;7:22-33.

4. Ngadino, Setiawan, Koerniasari, Ernawati, Sudjarwo SA: Evaluation of antimycobacterial activity of Curcuma xanthorrhiza ethanolic extract against Mycobacterium tuberculosis H37Rv in vitro. Vet World 2018;11:368-372.

5. Dzoyem JP, Aro AO, Mcgaw, LJ, Eloff JN: Antimycobacterial activity against different pathogens and selectivity index of fourteen medicinal plants used in southern Africa to treat tuberculosis and respiratory ailments. S Afr J Bot 2016;102:70-74.

6. Nguta JM, Appiah-Opong AK, Nyarko D, et al.: Antimycobacterial and cytotoxic activity of selected medicinal plant extracts. J Ethnopharmacol 2016;182:10-15.

7. Kumar KPS, Bhowmik D, Duraivel S, Umadevi M: Traditional and medicinal uses of banana. J Pharmacogn Phytochem 2012;1:51-63.

8. Imam MZ, Akter S: Musa paradisiaca L. and Musa sapientum L.: A phytochemical and pharmacological review. J Appl Pharm Sci 2011;01:14-20.
9. Molina-Salinas GM, Martínez-Rodríguez HG, Ortega-García JL, Martínez-Martínez YB, Garza-Treviño EN, Said-Fernández S: Musa $\times$ paradisiaca L. (banana): hexane leaf- and ethyl acetatrhizome-extracts are active on Mycobaterium tuberculosis resistant to first-line antitubercular medications. Rev Mex Cienc Farm 2016;47:66-73.

10. Balick MJ, Arvigo R: Plants of Belize and their uses in ancient and contemporary times and ethnobotanical compendium. In: Messages from the Gods: A guide to the Useful Plants of Belize, Oxford University Press, New York, 2015, pp. 149150.

11. Manzanilla-Interian AM: Medicinal plants in Oxkutzcab, a reencounter with our Maya roots. Universidad Autónoma Chapingo, México, 2009, p. 49.

12. Flores JS, Ricalde-Vermont R: The secretions and exudates of plants used in Mayan traditional medicine. J Herbs Spices Med Plants 1996;4:53-59.

13. Barrera A, Barrera-Vasquez A: "Medicina domestica". In: $E l$ libro del Judio, Compañia editorial Continental, S.A de C.V., México D.F., 1983, p. 5.

14. Molina-Salinas GM, Ramos-Guerra MC, Vargas-VIllarreal J, Mata-Cárdenas BD, Becerril-Montes P, Said-Fernández S: Bactericidal activity of organic extracts from Flourensia cernua DC against strains of Mycobacterium tuberculosis. Arch Med Res 2006;37:45-49.

15. Skehan P, Storeng R, Scudiero D, et al.: New colorimetric cytotoxicity assay for anticancer-drug screening. J Natl Cancer Inst 1990;82:1107-1112.

16. Machana S, Weerapreeyakul N, Barusrux S, Nonpunya A, Sripanidkulchai B, Thitimetharoch T: Cytotoxic and apoptotic effects of six herbal plants against the human hepatocarcinoma (HepG2) cell line. Chin Med 2011;6:2-9.

17. Kuete V: Potential of cameroonian plants and derived products against microbial infections: A review. Planta Med 2010;76: 1479-1491.

18. Mohamad S, Ismail NN, Parumasivam T, Ibrahim P, Osman H: Antituberculosis activity, phytochemical identification of Costus speciosus (J. Koenig) Sm., Cymbopogon citratus (DC. Ex Nees) Stapf., and Tabernaemontana coronaria (L.) Willd. and their effects on the growth kinetics and cellular integrity of Mycobacterium tuberculosis H37Rv. BMC Complement Altern Med 2018;18:1-14.

19. Vonthron-Sénécheau $\mathrm{C}$, Weniger $\mathrm{B}$, Ouattara $\mathrm{M}$, et al.: In vitro antiplasmodial activity and cytotoxicity of ethnobotanically selected Ivorian plants. J Ethnopharmacol 2003;87:221-225.

20. Karuppiah P, Mustaffa M: Antibacterial and antioxidant activities of Musa sp. leaf extracts against multidrug resistant clinical pathogens causing nosocomial infection. Asian Pac J Trop Biomed 2013;3:737-742.

21. Accioly MP, Bevilaqua CM, Rondon FC, et al:: Leishmanicidal activity in vitro of Musa paradisiaca L. and Spondias mombin L. fractions. Vet Parasitol 2012;187:79-84.

22. Gemechu A, Giday M, Worku A, Ameni G: In vitro antimycobacterial activity of selected medicinal plants against $M y$ cobacterium tuberculosis and Mycobacterium bovis strains. BMC Complement Altern Med 2013;13:291-296. 